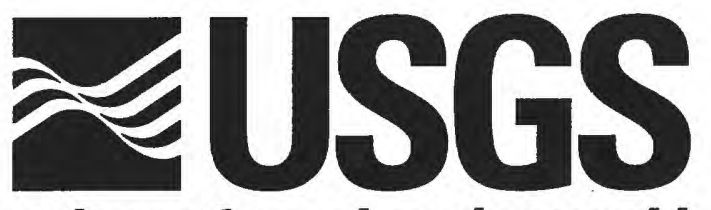

science for a changing world

\title{
Volcano Hazards from Mount Rainier, Washington, Revised 1998
}

Open-File Report 98-428

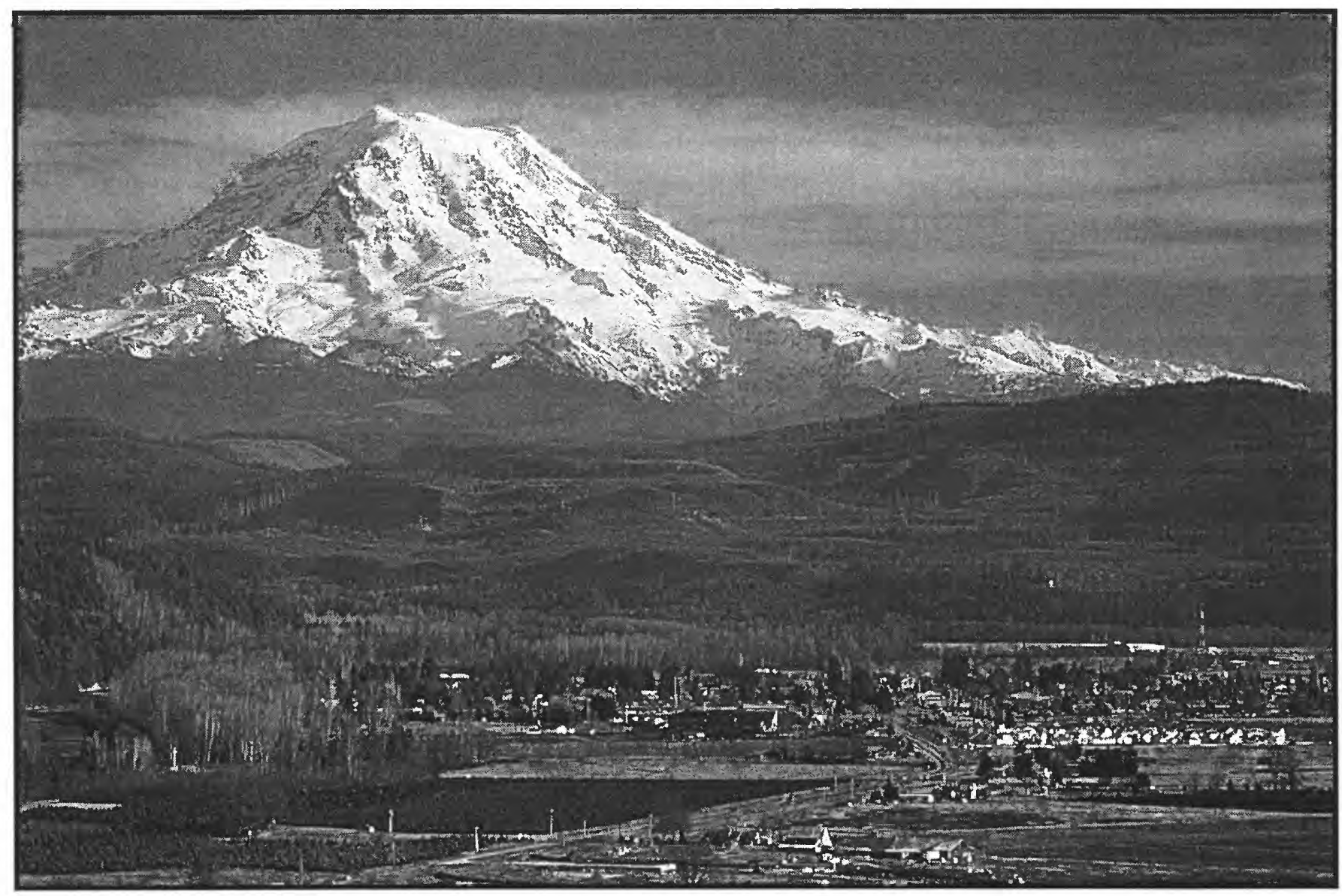

U.S. Department of the Interior

U.S. Geological Survey 
This page intentionally left blank 
U.S. Department of the Interior

U.S. Geological Survey

\section{Volcano Hazards from Mount Rainier, Washington, Revised 1998}

\section{By R.P. Hoblitt1, J.S. Walder1, C.L. Driedger1, K.M. Scott1, P.T. Pringle2, J.W. Vallance³}

1. U.S. Geological Survey, Cascades Volcano Observatory, 5400 MacArthur Blvd., Vancouver, WA 98661

2. Washington State Dept. of Natural Resources, Division of Geology and Earth Resources, P.O. Box 47007, Olympia, WA 98504

3. McGill University, Department of Civil Engineering and Applied Mechanics, 817 Sherbrooke St. West, Montreal, QC, H3A 2K6, Canada

\section{Open-File Report 98-428}


U.S. Department of the Interior

Bruce Babbitt, Secretary

U.S. Geological Survey

Thomas J. Casadevall, Acting Director

This report is preliminary and has not been reviewed for conformity with U.S. Geological Survey editorial standards or with the North American Stratigraphic Code. Any use of trade, firm, or product names is for descriptive purposes only and does not imply endorsement by the U.S. Government.

To purchase USGS publications contact:

U.S. Geological Survey

Information Services

P.O. Box 25286

Denver, CO 80225

(303) 202-4210 


\section{Contents}

Introduction . . . . . . . . . . . . . . . . . . . . . . . . . . . . . . 1

Revisions in this Report . . . . . . . . . . . . . . . . . . . . . . . . . . 1

Hazardous phenomena at Mount Rainier . . . . . . . . . . . . . . . . . 2

Tephra . . . . . . . . . . . . . . . . . . . . . . . . . . 2

Ballistic projectiles . . . . . . . . . . . . . . . . . . . . . . . . . . . 4

Pyroclastic flows and pyroclastic surges . . . . . . . . . . . . . . . . . . . . . 4

Lava flows . . . . . . . . . . . . . . . . . . . . . . . . . . 4

Volcanic gases . . . . . . . . . . . . . . . . . . . . . . . . . . . . 5

Debris avalanches and lahars . . . . . . . . . . . . . . . . . . . 5

Lateral blasts . . . . . . . . . . . . . . . . . . . . . . . . 6

Glacial outburst floods . . . . . . . . . . . . . . . . . . . . . . . . 7

What will happen when Mount Rainier reawakens? $\quad$. . . . . . . . . . . . . . . 7

Protecting our communities and ourselves from volcano hazards . . . . . . . . . . . . 8

Volcano-hazard maps . . . . . . . . . . . . . . . . . . . . . . . . . . . 8

Hazard zonation for debris avalanches and lahars . . . . . . . . . . . . . . . . 9

Hazard zonation for pyroclastic flows . . . . . . . . . . . . . . . . . . . 10

Hazard zonation for tephra fall . . . . . . . . . . . . . . . . . . . . . . 10

Hazard zonation for laterally directed blasts . . . . . . . . . . . . . . . . . 10

Suggestions for further reading . . . . . . . . . . . . . . . . . . . . . . 11

\section{Illustrations}

Plate I Volcano hazards from Mount Rainier, Washington ․ . . . . . . In pocket

Pyroclastic-flow hazard zone and inundation zones

for Case I, II, and III lahars

Plate II Volcano hazards from Mount Rainier, Washington

In pocket

Map A. Total Cascades tephra hazards

Map B. Mount Rainier tephra hazards

Map C. Low-probability, high-consequence events

Map D. Lower White and Green Rivers, and Duwamish River (continued from Plate I)

Map E. Lower Nisqually River (continued from Plate I)

Figure 1. Pumice-producing eruptions at Mount Rainier during the past 10,000 years . . 3

Cover photo: View of Mount Rainier from across Puyallup River valley near Orting, Washington.

Dave Wieprecht, U.S. Geological Survey 


\title{
Volcano Hazards from Mount Rainier, Washington, Revised 1998
}

\author{
By R.P. Hoblitt, J.S. Walder, C.L. Driedger, K.M. Scott, P.T. Pringle, J.W. Vallance
}

\section{Introduction}

Mount Rainier-at 4393 meters $(14,410$ feet) the highest peak in the Cascade Range-is a dormant volcano whose load of glacier ice exceeds that of any other mountain in the conterminous United States. This tremendous mass of rock and ice, in combination with great topographic relief, poses a variety of geologic hazards, both during inevitable future eruptions and during the intervening periods of repose.

The volcano's past behavior is the best guide to possible future hazards. The written history of Mount Rainier encompasses the period since about A.D. 1820, during which time one or two small eruptions, several small debris avalanches, and many small lahars (debris flows originating on a volcano) have occurred. This time interval is far too brief to serve as a basis for estimating the future behavior of a volcano that is several hundreds of thousands of years old. Fortunately, prehistoric deposits record the types, magnitudes, and frequencies of past events, and show which areas were affected by them. At Mount Rainier, as at other Cascade volcanoes, deposits produced since the latest ice-age (approximately during the past 10,000 years) are well preserved. Studies of these deposits reveal that we should anticipate potential hazards from some phenomena that only occur during eruptions and from others that may occur without eruptive activity. Tephra falls, pyroclastic flows and pyroclastic surges, ballistic projectiles, and lava flows occur only during eruptions. Debris avalanches, lahars, and floods commonly accompany eruptions, but can also occur during dormant periods.

This report (1) explains the various types of hazardous geologic phenomena that could occur at Mount Rainier, (2) shows areas that are most likely to be affected by the different phenomena, (3) estimates the likelihood that the areas will be affected, and (4) recommends actions that can be taken to protect lives and property. It builds upon and revises a similar document prepared by D.R. Crandell in 1973. Our revision was motivated by the availability of new information about Mount Rainier's geologic history, by advances in the field of volcanology, and by the need to assess hazards in a more quantitative manner than in Crandell's pioneering report.

\section{Revisions in this report}

This report revises U.S. Geological Survey Open-File Report 95-273, Volcano Hazards from Mount Rainier, Washington, published in 1995. The following revisions apply to the case histories defined later in this report and shown on Plates I and II: (1) extension of Case I and Case II lahar-inundation zones for lahars originating in the Puyallup valley drainage (pl. I), (2) addition of a zone of potential inundation hazard in the lower Nisqually River valley caused by a Case I lahar entering and possibly flowing beyond Alder Reservoir (pls. I and II), and (3) addition of a zone of post-lahar sedimentation extending north from the White River alluvial fan in southern Auburn 
through the lower Green River and Duwamish River valleys to Elliott Bay (pls. I and II).

The original Electron Mudflow, which was used to define the Case I inundation zone in the Puyallup River valley, inundated flood plains that were covered by a mature old-growth forest. A modern flow of the same size would spread farther and faster across flood plains that are now deforested and thus hydraulically smoother; indeed, one estimate is that such a modern flow might inundate 40 percent more area. A Case I lahar, occurring today, could destroy all of parts of Orting, Sumner, Puyallup, Fife, the Port of Tacoma, and possibly Auburn. The revised Case I inundation zone reflects our concern about the greater mobility of a modern Case I flow.

Extension of the Case II inundation zone to the mouth of the Puyallup River valley and north of Sumner (pls. I and II) reflects the recent discovery of lahar-related deposits from Mount Rainier that apparently filled the lower Duwamish River valley from wall to wall as far as Elliott Bay in Puget Sound. These include deposits of a type thought to represent the dilute, or watery, distal part of an eruption-generated lahar.

Alder Lake, on the Nisqually River, is shallow and has a storage capacity of less than the Case I lahar volume. Because Alder Dam exists for power generation, Alder Lake is never empty, and we are concerned that a Case I flow entering the reservoir could either cause failure of the dam or could catastrophically displace a significant volume of the water in storage. The inundation zone now shown downstream from Alder Dam (pls. I and II) is similar to that determined for a sudden failure of the dam (City of Tacoma Department of Public Utilities, 1997, Nisqually River; Alder and Lagrande Dam failure flood inundation maps).

The topographically low floor of the contiguous lower Green River and Duwamish River valleys, from Auburn north to Elliott Bay (pl. II), is considered to be at significantly less (but not eliminated) risk of inundation by a Case I lahar, relative to that risk in the lower White River valley. This area will also be at significant risk from Case II lahars or from subsequent redistribution of sediment from new lahar deposits under either of the two following conditions: (1) lahars or post-lahar sedimentation significantly reduce the available storage of Mud Mountain Reservoir; (2) aggradation of the lower White River valley south of Auburn by lahars or post-lahar sedimentation from Puyallup valley causes the White and Puyallup Rivers to drain northward into the Green and Duwamish River valley.

\section{Hazardous phenomena at Mount Rainier}

Most of the many geologic phenomena that we describe here would only affect the immediate vicinity of Mount Rainier. However, tephra falls and lahars could affect great numbers of people far from the volcano. Tephra is commonly dispersed by winds over broad areas, and although its effects can be quite disruptive, it is usually not lethal. In contrast, lahars are restricted to valleys that originate at the volcano, but their effects can be very severe. In terms of their potential effects, lahars from Mount Rainier constitute the greatest volcano hazard in the Cascade Range.

\section{Tephra}

Explosive eruptions typically produce vertical plumes of hot gases mixed with volcanic rock particles. If the mixture is less dense than air, it rises over the volcano's vent until it reaches an altitude at which it ceases to be buoyant. As the plume rises, its ability to support particles progressively diminishes. Eventually, the particles in the plume (tephra, or volcanic ash) will be carried downwind and will fall to produce a deposit that covers a broad area. Tephra deposit thicknesses and particle sizes usually decrease with increasing distance from the volcano. Near the vent, large eruptions can produce tephra thicknesses of many meters (yards), containing fragments as large as tens of centimeters (10-20 inches) across. At hundreds of kilometers (hundreds of miles) from the vent, tephra deposits typically consist of a trace to a few $\mathrm{cm}$ (few inches) of dust to silt-sized particles.

Large tephra fragments are capable of causing death or injury by impact, and may be hot enough to start fires where they land. These hazards 
usually do not extend beyond about 10 kilometers (6 miles) from the vent. Most tephra-related injuries, fatalities, and social disruption occur at a greater distances from the vent, where tephra fragments are less than a few centimeters ( 1 inch) across. Clouds of fine tephra can block sunlight, greatly restrict visibility, and thereby slow or stop vehicle travel. Such clouds are commonly accompanied by frequent lightning. The combination of near or total darkness, lightning, and falling tephra can be terrifying. When inhaled, tephra can create or aggravate respiratory problems. Accumulation of more than about 10 centimeters ( 4 inches) of tephra on the roof of a building may cause it to collapse. Even thin tephra accumulations ruin crops. Wet tephra can cause power lines to short out. Fine tephra is abrasive and can damage mechanical devices and increase maintenance problems. Finally, tephra clouds are extremely hazardous to aircraft, because engines may stop and pilots may not be able to see.

The hazard from tephra fall is, in general, less severe than that of some other volcanic phenomena and therefore may not be given adequate attention during planning for volcanic crises. However, the 1980 eruptions of Mount St. Helens show that even thin accumulations of tephra can profoundly disrupt social and economic activity over broad areas. For example, the Washington communities of Yakima, Ritzville, and Spokane experienced significant disruptions in transportation, business activity, and community services when 6 to 80 millimeters ( $1 / 4$ to 3 inches) of tephra fell. The greater the amount of tephra that fell, the longer a community took to recover. Residents found that tephra falls of less than 6 millimeters (1/4 inch) were a major inconvenience, and that falls of more than 17 millimeters ( $2 / 3$ inch) were a disaster. Nonetheless, all three communities returned to nearly normal activities within two weeks.

Mount Rainier is a moderate tephra producer relative to other Cascade volcanoes. Eleven eruptions have deposited layers of frothy tephra (pumice) near Mount Rainier in the past 10,000 years (fig. 1), most recently in the first half of the nineteenth century. Pumice layers are produced by eruptions of gas-rich magma (molten rock).

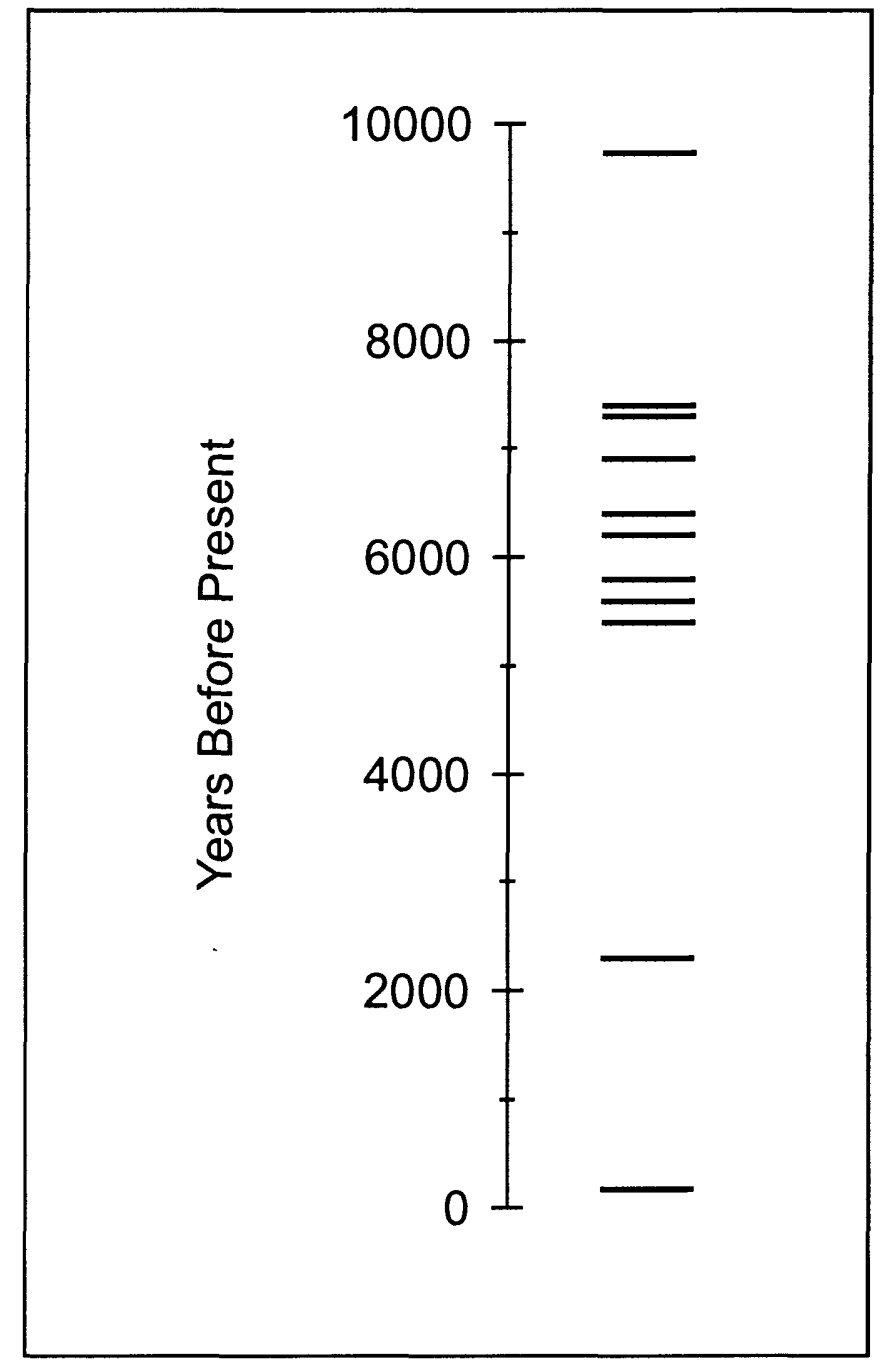

Figure 1. Pumice-producing eruptions at Mount Rainier during the past 10,000 years.

At least 25 layers of non-pumice-bearing (lithic) material lie between the pumice layers. Most if not all of this material was probably produced by eruptions of gas-poor magma; some may have originated with eruptions driven by steam rather than magma.

Figure 1 shows that pumice-producing eruptions have been irregularly spaced through time, so it is impossible to predict when the next one will occur. On the basis of the evidence summarized in Figure 1, the average time interval between eruptions is about 900 years. This is a maximum estimate of the average time between eruptions because it considers neither eruptions that did not produce pumice nor small eruptions that did not produce recognizable deposits. 


\section{Ballistic projectiles}

Particles thrown from the vent on ballistic arcs, like artillery shells, are called ballistic projectiles. The maximum range of ballistic projectiles rarely exceeds 5 kilometers ( 3 miles) from the vent, and most projectiles are less than a meter (3 feet) across. The chief hazard from ballistic projectiles is from direct impact. Projectiles may still be quite hot when they land, and can start fires if they land near combustible materials.

\section{Pyroclastic flows and pyroclastic surges}

Sometimes the mixture of hot gases and volcanic rock particles produced by an explosive eruption is denser than air. Instead of rising above the vent to produce tephra, the mixture behaves like a fluid and flows downhill over the ground surface. If the mixture is made up mostly of rock particles, it has a high density and topography controls its path, just as topography controls the flow of water. Such a gas-poor mixture is called a pyroclastic flow. If the mixture is made up mostly of gas, with only a small proportion of rock fragments, it has a lower density and its path is weakly influenced by topography. Such a gas-rich mixture is called a pyroclastic surge. Pyroclastic flows and surges often occur simultaneously. In such cases, the pyroclastic flow will closely follow the course of a valley, while the pyroclastic surge will separate from the flow and continue straight ahead where the valley changes direction.

Pyroclastic flows and pyroclastic surges are exceedingly hazardous. They move at such high speeds that escape from them is difficult or impossible. Their speeds typically exceed 10 meters/second (20 miles/hour) and sometimes exceed 100 meters/second (200 miles/hour). Temperatures in pyroclastic flows are usually more than 300 degrees Celsius (570 degrees Fahrenheit). Because of their high densities, high velocities, and high temperatures, pyroclastic flows can destroy all structures and kill all living things in their paths by impact, burial, and incineration. The effects of pyroclastic surges may be less severe, because of lower densities and temperatures, but are still usually destructive and lethal. People and animals caught in pyroclastic surges may be killed by direct impact by rocks, severe burns, or suffocation.

Deposits of pyroclastic flows and surges exist at Mount Rainier, but they are not abundant. Pyroclastic-flow deposits about 2,500 years old occur in the South Puyallup River valley, about 12 kilometers (7.5 miles) southwest of the volcano's summit, and a thin surge deposit about 1000 years old has been found about 11 kilometers ( 7 miles) northeast of the summit, in the White River valley. The apparent dearth of pyroclastic flow and surge deposits may mean that Mount Rainier produces few of them, but a more likely reason is that most pyroclastic flows and surges are converted to debris flows as they pass over snow and ice. The hot rock fragments melt snow and ice, then mix with the melt water to form lahars. At least some of the many lahars produced by Mount Rainier in the past 10,000 years formed in this manner.

\section{Lava flows}

Much of Mount Rainier is composed of andesite lava flows. Lava flows are streams of molten rock that erupt relatively non-explosively from a volcano, then move downslope until they stop, cool, and solidify. Lava flows may accompany explosive eruptive activity, but they occur more often after explosive activity declines. The term "andesite" refers to the chemical composition of the rock. Andesite lavas tend to be very viscous and rather slow moving: on gentle slopes, they may move much more slowly than a person can walk. Although people and animals can escape them, lava flows destroy everything in their paths either by fire, impact, or burial. The primary hazard to people from lava flows is low, but a more serious hazard arises when such flows come into contact with snow and ice. The result is rapid melting, which is capable of generating floods and lahars. Some lahars from Mount Rainier may be the indirect products of lava flows.

The only lava flows known to have been erupted from Mount Rainier in the past 10,000 years are those that built the summit cone, which was constructed within the past 5,600 years. Some of these flows probably extended down the east side of the volcano, where their remnants form 
ridges of rock along the central part of Emmons Glacier.

\section{Volcanic gases}

All magmas contain dissolved gases that are released during and between eruptive episodes. Gases from andesitic volcanoes consist chiefly of water vapor, followed in abundance by carbon dioxide and sulfur compounds. Minor amounts of carbon monoxide, chlorine, fluorine, boron compounds, ammonia, and several other compounds may be present.

The distribution of volcanic gases is mostly controlled by the wind; they may be concentrated near a vent but become diluted rapidly downwind. People and animals can sustain injuries to their eyes and lungs from acids, ammonia, and other compounds present in volcanic gases, and can be suffocated by denser-than-air gases, such as carbon dioxide, which accumulate in closed depressions. Metals and other susceptible materials can be severely corroded.

Information about volcanic gases at Mount Rainier comes from studies of its hydrothermal system: the hot, mineral-laden waters within the volcano that feed fumaroles and hot springs at its surface. Gas samples collected from fumaroles at Mount Rainier's summit in 1982 consisted of air enriched with carbon dioxide; no sulfurous gases were detected. Sulfurous gases have been reported previously, however, from summit fumaroles. Currently (1998), volcanic gases are a significant hazard only to climbers who enter the summit ice caves. When the volcano reawakens, however, the gas-emission rate will increase, as will the potential hazard from volcanic gases.

\section{Debris avalanches and lahars}

The slopes of a volcano may become unstable and fail, generating a rapidly moving landslide called a debris avalanche. Sometimes the instability is caused by magma forcing its way into the volcano. The magma pushes the old rocks aside, and creates a bulge that can break away from the rest of the volcano and produce a debris avalanche. The best-known historic example of a magmatically induced debris avalanche occurred in 1980 at Mount St. Helens.

A volcano's slopes can also fail without the direct involvement of magma. Stability slowly declines as slopes are oversteepened by glacial erosion or as the strength of the rock is reduced. The latter occurs when rocks within the volcano are subjected to the hot, acidic waters of a hydrothermal system over an extended period of time. The rock becomes weaker as it is chemically altered to clay and other minerals. Like a house infested with termites, the affected part of the volcano eventually becomes so weak that it collapses under its own weight, and generates a debris avalanche.

Non-magmatic debris avalanches are especially dangerous, because they can occur spontaneously, without any warning. Earthquakes, steam explosions, and intense rainstorms can trigger debris avalanches from parts of a volcano that have already been weakened by glacial erosion or hydrothermal activity.

A debris avalanche can travel tens of kilometers (tens of miles) at speeds of tens to hundreds of kilometers (tens to hundreds of miles) per hour, so that it is difficult or impossible to escape. Its path is strongly controlled by topography, and everything in its way will be destroyed by impact and incorporated into the avalanche. The resulting deposit is usually a few meters (yards) to hundreds of meters (hundreds of yards) thick, with an hummocky surface. When a large debris avalanche moves down a valley, its deposits can block the mouths of tributary valleys, and cause lakes to form. When impounded water spills over the blockage, it can quickly cut a channel and cause the lake to drain catastrophically, generating lahars and floods. This may occur hours to months after the impoundment.

Whatever their origin, debris avalanches commonly contain enough water or incorporate enough water, snow, or ice to transform into lahars. Lahars are slurries of water and sediment (60 percent or more by volume) that look and behave much like flowing concrete. Lahars are sometimes called mudflows, as in Osceola Mudflow (pl. II). Lahars can travel at speeds of a few tens of kilometers (miles) per hour along gently sloping distal valleys, but higher speed 
(more than 100 kilometers (60 miles) per hour) are possible on steep slopes near the volcano. They can damage or destroy many structures in their paths by impact or burial. Their paths are strongly controlled by topography. Reservoirs in valleys downstream from the volcano may be partly or wholly filled by lahars moving downvalley, so if the water level of a reservoir is not lowered in time, water displaced by a lahar could cause floods farther downstream.

During the past 10,000 years, at least 60 lahars of various sizes have moved down valleys that head at Mount Rainier. All these can be grouped into two categories, called cohesive and non-cohesive lahars. Cohesive lahars form when debris avalanches originate from water-rich, hydrothermally altered parts of the volcano.

They are cohesive because they contain relatively large amounts of clay derived from chemically altered rocks. Non-cohesive lahars, in contrast, contain relatively little clay. Mount Rainier's non-cohesive lahars are triggered whenever water mixes with loose rock debris, such as the mixing of pyroclastic flows or pyroclastic surges with snow or ice; relatively small debris avalanches; unusually heavy rain; or abrupt release of water stored within glaciers.

The largest lahar originating at Mount Rainier in the last 10,000 years is known as the Osceola Mudflow. This cohesive lahar, which occurred about 5600 years ago, was at least 10 times larger than any other known lahar from Mount Rainier. It was the product of a large debris avalanche composed mostly of hydrothermally-altered material, and may have been triggered as magma forced its way into the volcano. Osceola deposits cover an area of about 550 square kilometers (212 square miles) in the Puget Sound lowland, extending at least as far as the Seattle suburb of Kent, and to

Commencement Bay, now the site of the Port of Tacoma. The communities of Orting, Buckley, Sumner, Puyallup, Enumclaw, and Auburn are also wholly or partly located on top of deposits of the Osceola Mudflow and, in some cases, of more recent debris flows as well.

At least 6 smaller debris avalanches have spawned lahars in the past 5,600 years. One of these, the Electron Mudflow, which was derived from a slope failure on the west flank of Mount
Rainier about 600 years ago, has not been correlated with an eruption. The Electron Mudflow was more than 30 meters (yards) deep where it entered the Puget Sound lowland at the community of Electron. Its deposits at Orting are as much as 6 meters (yards) thick and contain remnants of an old-growth forest.

Large non-cohesive lahars at Mount Rainier are associated with volcanism. About 1,200 years ago, a lahar of this type filled valleys of both forks of the White River to depths of 20 to 30 meters (60 to 90 feet) and flowed $100 \mathrm{~km}$ (60 miles) to Auburn. Hot rock fragments flowing over glacier ice and snow generated huge quantities of melt water, which mixed with the rock debris to form lahars. Less than 2200 years ago, another lahar of similar origin, named the National Lahar, inundated the Nisqually River valley to depths of 10 to 40 meters (30-120 feet) and flowed all the way to Puget Sound. More than a dozen lahars of this type have occurred at Mount Rainier during periods of volcanism in the past 6,000 years.

Circumstances conducive to future debris avalanches and lahars-substantial volumes of hydrothermally altered rock, substantial topographic relief, great volumes of ice, and the potential for renewed volcanism-are all present at Mount Rainier. Thus, lahars are a greater threat to communities downvalley from Mount Rainier than any other volcanic phenomenon.

\section{Lateral blasts}

When the side of a shallow magma body or hydrothermal system is suddenly depressurized, a laterally directed explosion produces a pyroclastic surge that can travel tens of kilometers (tens of miles) from the volcano. The explosion and resultant surge is usually called a "lateral blast". The best-known example occurred in 1980 at Mount St. Helens, when a body of magma accumulated within the volcano over a period of 52 days and caused the north flank of the volcano to bulge outward. Stresses caused by the bulging grew so great that the northern sector broke away from the rest of the volcano and produced a great debris avalanche. The depressurized magma body and surrounding hydrothermal system then exploded, producing a lateral blast. Both the 
debris avalanche and the lateral blast traveled a maximum distance of about 28 kilometers (17 miles).

The debris avalanche that produced the Osceola Mudflow at Mount Rainier was apparently accompanied by at least one laterally directed explosion as the hydrothermal system was depressurized. Some evidence suggests that there may have been as many as three explosions. The association of pumice-bearing tephras with the explosion deposits suggests that the debris avalanche was triggered by the rise of magma into the volcano.

With adequate monitoring, lateral blasts caused by magma moving into a volcano can be predicted, because the magma causes the volcano to bulge. However, lateral blasts may occur without the direct involvement of magma. This can happen when a non-magmatic debris avalanche uncovers an active hydrothermal system, which then explodes. Three factors conducive to a non-magmatic debris avalanche and explosion -substantial volumes of weak hydrothermally altered rock, substantial topographic relief, and an active hydrothermal system-are now present at Mount Rainier.

\section{Glacial outburst floods}

Glacial outburst floods at Mount Rainier result from sudden release of water stored within or at the base of glaciers. Outburst floods and the lahars they often trigger pose a serious hazard in river valleys on the volcano. The peak discharge of an outburst flood may be greater than that of an extreme meteorological flood (such as the 100-year flood commonly considered in engineering practice) for any given stream valley. At least three dozen outburst floods have occurred during the 20th century. Bridges, roads, and National Park visitor facilities have been destroyed or damaged on about ten occasions since 1926. However, the effects of outburst floods are rarely noticeable outside the boundaries of Mount Rainier National Park. Because they commonly transform downvalley to lahars, outburst floods are included with lahars for purposes of hazard zonation.

Outburst floods have been recorded from the Kautz, Nisqually, South Tahoma and Winthrop glaciers on Mount Rainier. Many of these outburst floods transformed to lahars by incorporating large quantities of sediment from channel walls and beds. Availability of this sediment is related to climate change that has caused glaciers on Mount Rainier to retreat substantially since the mid-19th century. During glacier retreat, stagnant masses of sediment-rich glacier ice have been stranded in valleys downstream of present-day glaciers. These stagnant ice masses are readily eroded by floods. However, over the span of the next few decades, as the stagnant ice melts, stream channels should become more stable and less readily affected by outburst floods.

Glacial outburst floods at Mount Rainier are unrelated to volcanic activity. The best-studied outbursts-those from South Tahoma Glacierare correlated with periods of unusually high temperatures or unusually heavy rain in summer or early autumn. The exact timing of outbursts is unpredictable, however.

\section{What will happen when Mount Rainier reawakens?}

Volcanoes usually provide warning signals days to months before they erupt. As magma pushes its way upward, it shoulders aside the old rocks and produces earthquakes, and causes the sides of the volcano to deform slightly. Neither the earthquakes nor the deformation may be apparent to people, but they are detectable by sensitive instruments. Heat and gases from the rising magma may cause changes in the temperature, discharge rate, and composition of hot springs and fumarolic vapors.

Earthquakes near Mount Rainier are continuously monitored by a network of seismometers maintained under the auspices of the U.S. Geological Survey Volcano Hazards Program and the University of Washington Geophysics Program. In a typical year, this network detects a few hundred earthquakes that occur at or near Mount Rainier. At the first sign of unusual earthquake activity, scientists from the Geological Survey and other institutions will deploy additional instruments on and around Mount Rainier to monitor earthquakes, deformation, and 
other symptoms of volcanic unrest. The monitoring information will be used to assess the state of unrest and to issue appropriate advisories and warnings to emergency-response officials and the public. Symptoms of volcanic unrest at Mount Rainier would greatly increase the probability of debris avalanches, especially those of large size that might affect populated areas in the Puget Sound lowland.

Periods of volcanic unrest are usually times of great uncertainty. Although outstanding advances have been made in volcano monitoring and eruption forecasting over the past few decades, scientists are often able to make only very general statements about the probability, type, and scale of an impending eruption. Precursory activity can wax and wane, and sometimes dies out without leading to an eruption. Government officials and the public should realize the limitations in forecasting eruptions and be prepared for such uncertainty.

\section{Protecting our communities and ourselves from volcano hazards}

Communities, businesses, and citizens can undertake several actions to mitigate the effects of future eruptions, debris avalanches, and lahars. Decisions about land use and siting of critical facilities can incorporate information about volcano hazards. Areas judged to have an unacceptably high risk can be left undeveloped. Alternatively, development can be planned to reduce the level of risk, or even include engineering measures to mitigate risk. For example, areas along the channels and flood plains of lahar-prone rivers could be set aside for open space or recreation, and valley walls or high terraces could be used for houses, schools, and businesses.

An eruption or the threat of an eruption requires short-term emergency responses. Such responses will be most effective if citizens and public officials understand volcano hazards and have planned the actions needed to protect communities. Because the time can be short (days to months) between onset of precursory activity and an eruption, and because some hazardous events can occur without warning, appropriate emergency plans should be made and practiced beforehand. Public officials need to consider issues such as public education, communications, and evacuations. Emergency plans already developed for floods may be applicable, with modifications, to hazards from lahars in valleys that head on Mount Rainier.

Businesses and individuals should also make plans to deal with volcano emergencies. Planning is prudent because once an emergency begins, public resources can often be overwhelmed, and citizens may need to provide for themselves and make informed decisions. The Red Cross recommends numerous items that should be kept in homes, cars, and businesses for many types of emergencies that are much more probable than a volcanic eruption. Other items that will help include a map showing the best route to high ground.

The most important additional item is knowledge about volcano hazards and, especially, a plan of action based on the relative safety of areas around home, school, and work. Be aware of the location of the volcano and valleys that may be affected by lahars. If your house is within a hazard zone for debris avalanches and lahars, and if you learn that a hazardous event may be in progress, move to higher ground nearby. If this is not possible, move downvalley and then move to higher ground at the first opportunity. A safe height above river channels depends on the size of the lahar, distance from the volcano, and shape of the valley. For all but the largest lahars, areas 50 meters ( 160 feet) or more above river level will be safe.

\section{Volcano-hazard maps}

The accompanying maps (pls. I and II) show areas that could be affected in the future by (1) debris avalanches and lahars, (2) pyroclastic flows, surges, lava flows, and ballistic projectiles, (3) tephra falls, and (4) lateral blasts. Although we show boundaries of hazard zones by lines, the degree of hazard does not change abruptly at these boundaries. Rather, the hazard decreases gradually away from the volcano and, for flows, with height above the valley floor. Areas immediately beyond outer hazard zones should not 
be regarded as hazard-free, because the boundaries can only be approximately located, especially in areas of low relief. Too many uncertainties exist about the source, size and mobility of future events to locate hazard-free zones with absolute confidence.

\section{Hazard zonation for debris avalanches and lahars}

The boundaries of the lahar hazard zones (pls. I and II) are based on the behavior of flows that occurred during the past several thousand years. By examining the deposits of a particular flow, the cross-sectional area that it occupied at various distances from the source can be determined. The same relation between area and distance is then assumed to be applicable to a future flow of about the same volume, even though the future flow may move down a different river valley. This should be a reasonable approximation as long as the various river valleys originating at Mount Rainier have similar cross-sectional shapes and present similar resistance to passage of a lahar.

Past lahars at Mount Rainier have varied tremendously in size. For purposes of hazards assessment, four classes of lahars, with generally different modes of origin, are considered separately. In order of decreasing size and increasing frequency, these are called Case M, Case I, Case II, and Case III lahars.

The largest lahar to occur at Mount Rainier in the past 10,000 years is the Osceola Mudflow, which was ten times larger than any other lahar from Mount Rainier within this time period. The Osceola Mudflow formed about 5,600 years ago when a massive debris avalanche of weak, chemically altered rock transformed into a lahar. Flows of this magnitude, termed Case $M$ flows, are too infrequent to estimate an annual probability. The area that could potentially be affected by such a low-probability, high-consequence lahar is shown on Map C (pl. II).

Case I flows have occurred on average about once every 500 to 1000 years during the last 5,600 years. The annual probability of such a flow originating somewhere on Mount Rainier is thus about 0.1 to 0.2 percent. Most Case I flows have reached some part of the Puget Sound lowland. Although they are smaller than the Osceola Mudflow, these flows also originate from debris avalanches of weak, chemically altered rock. Evidence linking Case I flows with magmatic eruptions is inconclusive, so it should not be assumed that detectable precursory activity - such as seismicity owing to magma movement-would precede a large debris avalanche. The Electron Mudflow, which reached the Puget Sound lowland about 600 years ago along the Puyallup River, is considered to be a characteristic Case I flow for purposes of identifying probable inundation areas on Plates I and II.

Case II flows have a typical recurrence interval near the lower end of the 100- to 500-year range. The annual probability of such a flow is therefore close to 1 percent for the volcano as a whole, so for planning purposes Case II flows are analogous to the 100-year flood commonly considered in engineering practice. Some Case II flows have inundated flood plains well beyond the volcano, and a few have reached the Puget Sound lowland. Case II flows have relatively low clay contents; the most common origin for this class of flows is melting of snow and glacier ice by hot rock fragments during a volcanic eruption. However, as with Case I flows, non-eruptive origins are also possible, and there may be no precursory signals. For example, the most recent Case II flow, in 1947 , was triggered by heavy rain and also involved release of water stored within a glacier. The National Lahar, which occurred less than about two thousand years ago in the Nisqually River valley, is considered a characteristic Case II flow for purposes of identifying probable inundation areas on Plates I and II.

Case III flows are relatively small but occur frequently, with recurrence intervals of 1 to 100 years for the volcano as a whole. This class of flows includes small debris avalanches as well as lahars. Case III flows are not eruptively triggered. They are largely restricted to the slopes of the volcano, and rarely move beyond the National Park boundary. The most common Case III flows are lahars triggered by sudden, unpredictable release of water stored by glaciers. About three dozen such flows have occurred during the 20th century. The most dangerous Case III flows, however, are associated with less frequent, 
moderately large debris avalanches or other kinds of slope failures that may or may not transform to lahars. A lahar that occurred about 500 years ago in the valley of Tahoma Creek is considered a characteristic Case III flow for purposes of identifying probable inundation areas on Plate I.

\section{Hazard zonation for pyroclastic flows}

The boundary of the pyroclastic-flow hazard zone (pl. I) was determined for pyroclastic flows and surges with a "mobility" similar to those that have occurred at Mount Rainier in the past 10,000 years. "Mobility" is here defined as the ratio $L / H$, where $H$ is the elevation difference between the eruptive vent and the farthest point reached by the flow or surge, and $L$ is the horizontal (map) distance between those same two points. To construct the pyroclastic-flow hazard zone, the eruptive vent was assumed to be at the summit, and a $L / H$ value of 4.2 was used.

This $L / H$ value produces a hazard zone boundary that extends a few kilometers (about 2 miles) beyond all of Mount Rainier's known pyroclastic-flow and pyroclastic-surge deposits. The boundary was placed beyond the known limits of pyroclastic flows and surges to provide a margin of safety. The zone is irregular because of the irregular topography around Mount Rainier, which influences the paths of pyroclastic flows and surges.

In future eruptions, pyroclastic flows and surges, as well as lava flows and ballistic projectiles, probably will not extend beyond this zone. During any single eruption, some drainages may be unaffected by any of these phenomena, while other drainages may be partly or wholly affected by some or all of them.

The frequency with which this zone is affected by can be estimated from eruptions recorded by tephra and lahar deposits. The maximum average time between pumice-bearing eruptions is about 900 years. Case II lahar deposits provide a minimum estimate of the average time between eruptions - 100 years-because most Case II lahars are thought to be products of eruptions, and the average time between these flows is about 100 to 500 years. Thus, the annual probability of pyroclastic flows, surges, lava flows, and ballistic projectiles affecting some part of the pyroclastic-flow hazard zone is between about 0.1 and 1 percent.

\section{Hazard zonation for tephra fall}

Even small thicknesses of tephra can profoundly disrupt social and economic activity over broad areas. The thickness of tephra necessary to cause buildings to collapse depends on construction practices, but experience shows that failures tend to increase as the thickness approaches 10 centimeters (4 inches).

Consequently, tephra hazard is portrayed here with contour maps of the estimated annual probability of tephra accumulations of one centimeter $(0.4$ inch) or more and ten centimeters (4 inches) or more. Maps A1 and A2 (pl. II) consider all major Cascade volcanoes, while Maps B1 and B2 (pl. II) consider only eruptions from Mount Rainier. These estimates take into account the probability that the volcano will erupt, the probability that the specified tephra thickness will occur at a specified distance, and the probability that the wind will be blowing in a specified direction. Map B2 (pl. II) shows that tephra loads of 10 centimeters (4 inches) or more from eruptions of Mount Rainier are most likely to occur east of the volcano, within a few tens of kilometers (miles) of the summit. Most buildings within this area are designed to support substantial snow loads and thus may be relatively resistant to damage by tephra loading.

\section{Hazard zonation for laterally directed blasts}

The zone that could be affected by a laterally directed blast is shown on Map C (pl. II). The boundary of the hazard zone was determined for a lateral blast with "mobility" equal to that of the 1980 Mount St. Helens blast, which was much more mobile than the pyroclastic flow and surge used to construct the pyroclastic-flow hazard zone. An $L / H$ value of 11 was used, and the eruptive vent was assumed to be at the summit. Because Mount Rainier is substantially higher than Mount St. Helens, the potential blast-hazard zone is larger than the 1980 blast zone at Mount St. Helens. The boundary of the blast-hazard zone is irregular because of the irregular topography around Mount Rainier. The blast-hazard zone extends farthest to the northwest of the volcano because of the lack of 
high ridges or other topographic barriers in that direction.

A single lateral blast from Mount Rainier would not affect the entire zone shown on Map C (pl. II). Rather, experience at Mount St. Helens and other volcanoes suggests that a blast would affect a sector of no more than 180 degrees. During a volcanic crisis, the likelihood of a laterally directed blast could be assessed by monitoring seismicity and deformation of the flanks of the volcano. Formation of a bulge, as occurred at Mount St. Helens, would signal the strong likelihood of an imminent laterally directed blast, and identify the sector most likely to be affected. A refined hazard-zonation map could then be prepared indicating the sector at risk.

\section{Suggestions for further reading}

Blong, R.J., 1984, Volcanic hazards: Academic Press, Orlando, $424 \mathrm{p}$.

Crandell, D.R., 1971, Postglacial lahars from Mount

Rainier volcano, Washington: U.S. Geological Survey

Professional Paper 667, 75 p.
Crandell, D.R., 1973, Potential hazards from future eruptions of Mount Rainier: U.S. Geological Survey

Miscellaneous Geologic Investigations Map I-836.

Hoblitt, R.P., Miller, C.D., and Scott, W.E., 1987, Volcanic hazards with regard to siting nuclear-power plants in the Pacific Northwest: U.S. Geological Survey Open-File Report 87-297, $196 \mathrm{p}$.

Mullineaux, D.R., 1974, Pumice and other pyroclastic deposits in Mount Rainier National Park, Washington: U.S. Geological Survey Bulletin 1326, 83 p.

Saarinen, T.F. and Sell, J.L., 1985, Warning and response to the Mount St. Helens eruption: State University of New York Press, Albany, 240 p.

Scarpa, R., and Tilling, R.I., 1996, Monitoring and mitigation of volcanic hazards: Berlin, Springer-Verlag, $841 \mathrm{p}$.

Scott, K.M., Vallance, J.W., and Pringle, P.T., 1995, Sedimentology, behavior and hazards of debris flows at Mount Rainier, Washington: U.S. Geological Survey Professional Paper 1547, 56 p.

Sheridan, M.F., 1979, Emplacement of pyroclastic flows: a review: in Chapin, C.E., and Elston, W.E., eds., Ash-Flow tuffs, Geological Society of America Special Paper 180, p. 125-136.

Tilling, R.I., ed., 1989, Volcanic hazards: short course in geology, Vol. 1, American Geophysical Union, Washington, D.C., $123 \mathrm{p}$.

Walder, J.S., and Driedger, C.L., 1994, Geomorphic change caused by outburst floods and debris flows at Mount Rainier, Washington, with emphasis on Tahoma Creek valley: U.S. Geological Survey Water-Resources Investigations Report 93-4093, 93 p. 